\title{
ENCOURAGING BEHAVIORAL INTENTION TO USE MOBILE PAYMENT: AN EXTENSION OF UTAUT2
}

\author{
Hanif Adinugroho Widyanto ${ }^{1}$, Kunthi Afrilinda Kusumawardani ${ }^{2}$, Amreyzal \\ Septyawanda ${ }^{3}$
}

\author{
${ }^{1}$ School of Business, President University \\ Email: hanif@president.ac.id \\ ${ }^{2}$ School of Business, President University \\ Email: kunthi.kusumawardani@president.ac.id \\ ${ }^{3}$ Independent Researcher, Jakarta \\ Email: amreyzal@ymail.com
}

Masuk : 04-04-2020, revisi: 18-04-2020, diterima untuk diterbitkan : 18-04-2020

\begin{abstract}
ABSTRAK
Tujuan dari penelitian ini adalah untuk menganalisa faktor-faktor yang mempengaruhi minat menggunakan aplikasi pembayaran bergerak. Secara khusus, peneliti mengembangkan UTAUT2 (Unified Theory of Acceptance and Use of Technology) dengan menambahkan factor Persepsi Keamanan dan Kepercayaan untuk dapat menjelaskan variable endogenous pada penelitian ini dengan lebih baik. Sampel pada penelitian ini dibatasi pada pengguna sebuah brand pembayaran bergerak di daerah Jabodetabek, dengan data yang didapatkan melalui kuesioner online ( $n=144)$. Data pada penelitian ini diuji dengan menggunakan metode penelitian kuantitatif dengan menjalankan analisa SEM-PLS. Penelitian ini menemukan bahwa Pengaruh Sosial, Motivasi Keduniawian, dan Kepercayaan mempengaruhi Minat Menggunakan secara signifikan dan langsung, sedangkan Ekspektasi Usaha, Persepsi Keamanan, dan Ekspektasi Kinerja memiliki pengaruh tidak langsung terhadap Minat Menggunakan. Adjusted $\mathrm{R}^{2}$ dari variabel endogenous Minat Menggunakan pada penelitian ini adalah 71.6\%. Hasil dari penelitian ini memberikan kontribusi pada diskusi yang sedang berjalan terkait dengan penggunaan pembayaran bergerak sebagai 'disruptor digital' di masa mendatang dengan menambahkan dua variabel penting terkait privasi pengguna.
\end{abstract}

Kata Kunci: Pembayaran Bergerak, UTAUT2, Minat Menggunakan, Persepsi Keamanan, Kepercayaan

\begin{abstract}
The objective of this research is to analyze the antecedents of Behavioral Intention to use mobile payment platform. Specifically, the researchers expanded on UTAUT2 (Unified Theory of Acceptance and Use of Technology) by incorporating Perceived Security and Trust to better explain the endogenous variable. The sample of this study was limited to the users of mobile payment platforms in the Greater Jakarta area, and the data were collected using online questionnaires $(n=144)$. The data in this study were examined using quantitative research by utilizing the SEM-PLS analysis. This research found that Social Influence, Hedonic Motivation, and Trust directly and significantly affected Behavioral Intention, while Effort Expectancy, Perceived Security, and Performance Expectancy had an indirect relationship with Behavioral Intention. Finally, the adjusted $R^{2}$ of Behavioral Intention in this study is $71.6 \%$. The results of this study contributed to the ongoing discussion on mobile payment adoption as the next digital disruptor by incorporating two important user privacy constructs.
\end{abstract}

Keywords: Mobile Payment, UTAUT2, Behavioral Intention, Perceived Security, Trust

\section{INTRODUCTION}

These days, the ongoing development of technology is fostering intense competition in the modern business world (Jati \& Laksito, 2012). Companies must innovate and deliver creative business ideas to meet ever-increasing consumer needs (Elgin, 2013). A big focus of wealth creation for organizations is to look for opportunities in the dynamic company scape and profit from them using new technologies. In this regard, smartphones are considered as one of the most essential consumer goods ever introduced in the new economy (Aydin \& Burnaz, 2016). As a result, the number of smartphone devices has grown sharply in recent years, which supported the increasing mobility of the modern lifestyle (Schierz, Schilke, \& Wirtz, 2010). At the same time, in line with these developments, mobile services have increasingly become part of everyday life 
(Hwang, Shiau, \& Jan, 2007). This condition has led to the introduction and proliferation of mobile payment, which is a relatively new method of payment in which funds can be transferred electronically (Popovska-Kamnar, 2014). Mobile payment services attract consumers with their mobile device to pay for products or services seamlessly. In particular, electronic transactions via handheld devices offer consumers the ability to make payments a lot more efficient, comfortable, and useful (Phonthanukitithaworn, Sellitto, \& Fong, 2016).

In January 2019, Indonesia's total number of mobile internet users exceeded 150 million users, which account for $56 \%$ of the country's population at 268.20 million people (Basari, 2019). For electronic money, the data transactions in Indonesia are issued by Bank Indonesia (BI), and the difference between the number of electronic money transactions in 2017 and 2018 is quite significant, and even multiplied three-fold. In 2017, the amount of the transaction using the digital wallet in Indonesia was at Rp 12.37 trillion, whereas, in 2018, the number had reached Rp 47.19 trillion (Multazam, 2019). This condition is a strong indication that the Indonesian society has started its transition into a cashless movement. In 2019, the mobile payment industry in Indonesia is expected to play an even more prominent role in the total transaction of retail sales of the country. At the moment, the market is dominated by a few major players, such as Go-Pay, OVO, Dana, T-Cash/LinkAja, among others. Specifically, T-Cash was an online payment instrument introduced by Telkomsel, which is the largest mobile telecommunications provider in Indonesia. The latter boasts a total subscriber of around 15 million (Katadata.co.id, 2018). On 22 February 2019, T-Cash officially changed their name to LinkAja to provide "easier and faster financial services". In doing so, they collaborated with several leading state-owned enterprises, such as Pertamina, Bank BRI, Bank Mandiri, and Bank BNI (Pertiwi, 2019). However, based on the data from Katadata.co.id (2019), despite the considerable backing from major state-owned companies in the country, LinkAja could only secure the third position in the market as the most popular mobile payment product. Despite Telkomsel's massive user base, they were not interested in using LinkAja.

Therefore, the researchers are interested in discovering the predicting factors that could explain the behavioral intention to use mobile payment, specifically in the case of LinkAja. By definition, Behavioral Intention is the behavior of consumers who are loyal to the brand in order to recommend it to others because they have received excellent services from the company. Shiau (2014) explained that Behavioral Intention is considered to be defined by the subjective possibility of the particular behavior of an individual and reflects the individual's willingness to adopt particular behavior. Saha and Theingi (2009) defines Behavioral Intention as the customer's ability to do something positive about a service provider to people other than certain behaviors, such as word-of-mouth, with the intention of buying back and loyalty to the service provider. In this regard, to better understand the antecedents of Behavioral Intention, this study turned to the modified version of the Unified Theory of Acceptance and Use of Technology by Venkatesh, Thong, and Xu (2012), which was widely known as UTAUT2. This model is preferred since it is the improved version of the original UTAUT (Venkatesh, Morris, Davis, \& Davis, 2003), which is one of the most widely used models to evaluate the antecedents of behavioral intention to use new innovative products/services. The constructs from UTAUT2 that the researchers adopted in this study are Performance Expectancy (PE), Effort Expectancy (EE), Social Influence (SI), Facilitating Conditions (FC), and Hedonic Motivation (HM). The researchers also decided not to use Price Value and Habit since they are not relevant to the nature of mobile payment in this study. 
First, Performance Expectancy is the degree to which using technology in certain activities will benefit consumers (Venkatesh et al., 2012). The perception of the individual that using mobile payment will help achieve gains in payment tasks can thus affect the Behavioral Intention of mobile payment adoption (Oliveira, Thomas, Baptista, \& Campos, 2016). Sheikh, Islam, Rana, Hameed, and Saeed (2017) argue that Performance Expectancy is considered as constructs compared to other constructs that can provide robust predictions of technology use of interest. Individuals will be encouraged to use new technology when individuals benefit from using this technology in daily activities (Alalwan, Dwivedi, \& Rana, 2017). Next, Effort Expectancy is defined as the degree of ease associated with the use of a system (Venkatesh et al., 2003). In line with Davis (1989), considering the specific nature of mobile payment system which requires a certain level of knowledge and skill, Effort Expectancy could play a crucial role in determining the intention of customers to use these technology (Alalwan et al., 2017). Effort Expectancy is also understood as the degree of minimal effort connected with the use of technology by consumers (Venkatesh et al., 2012). It contributes to the prediction of new technology adoption (Lancelot Miltgen, Popovič, \& Oliveira, 2013). When users feel that mobile payment is simple to use and needs little effort, they expect higher performance (Venkatesh et al., 2003).

According to the UTAUT model, Social Influence is characterized as the extent to which a person considers other people's belief that a new system should be applied as important to them (Venkatesh et al., 2003). In the case of mobile payment, Social Influence could be conceptualized as the impact of the social environment on the customer's intention to adopt the system, such as reference groups, families, influencers, friends and peers (Zhou, Lu, \& Wang, 2010). The details and guidance taken by people around consumers could play a dynamic function in contributing to customer awareness and technological intention. The sampling of social influence as a key defining factor of behavioral intent is based on earlier works of literature that supported social impact on customers propensity to use online payment channels (Alalwan et al., 2017). Conversely, Facilitating Condition is defined as the degree to which a person considers an organizational and technical technology is available to support the use of the system (Venkatesh et al., 2003). Making conditions easier refers to consumers' perceptions of the resources and Support for conducting actions (Venkatesh et al., 2012). If there is an operational infrastructure and supports mobile payment, the Behavioral Intention to accept mobile payment will increase (Oliveira et al., 2016). In terms of Facilitating Condition, the government should seek to establish a favorable ecosystem in terms of omnipresent internet access as well as encourage merchants to offer their customers mobile payment as a means of payment and raise awareness of its availability and use (Sobti, 2019).

Finally, Hedonic Motivation is fundamental to human experience and behavior. As a result of hedonic pursuits, individuals enrich their subjective well-being and initiate and maintain useful behaviors. However, lasting fulfillment of Hedonic Motivation is troublesome due to adaptive effects (Kaczmarek \& Mickiewicz, 2017). Hedonic Motivation is the fun or pleasure of using technology. Hedonic Motivation was found to be a critical determinant of the adoption and use of technology in the consumer context (Venkatesh et al., 2012). As the enabler of a new form of financial transactions, Mobile Payments are enjoyable for users, leading to their acceptance (Oliveira et al., 2016). Hedonic Motivation is an extension of the concept of perceived enjoyment where shows Impact in technology acceptance. Definition of Perceived enjoyment determines the extent to which pleasure can be derived from use technology (Van Der Heijden, 2004). 
In addition, the present study is aimed at modifying UTAUT2 by adding a couple of critical constructs related to "user privacy" (Davies, Taft, Satyanarayanan, Clinch, \& Amos, 2016), namely, Perceived Security (Junadi \& Sfenrianto, 2015; Oliveira et al., 2016) and Trust (Lean, Zailani, Ramayah, \& Fernando, 2009; Wijoseno \& Ariyanti, 2017). This is important to further understand and stimulate customer's intention to use mobile payment platform. Furthermore, despite its urgency, the combination of UTAUT2 and user privacy constructs in this study has also never been comprehensively investigated in earlier literature, particularly in Indonesia, leaving a considerable gap that this study aims to fill. Trust is also an important issue for mobile payment since the past survey has revealed that 73.5 percent of customers are anxious about the perceived security of the platform (Y. Lu, Yang, Chau, \& Cao, 2011).

Perceived Security is defined as the degree to which people believe a particular technology or service to be secure (Kim, Mirusmonov, \& Lee, 2010). The degree to which security is perceived in the context of mobile payment and people believe that while using mobile payment, their property and privacy information is secure. Surveys that shed some light on the relationship between perceived security and users' mindset towards mobile payment use maintain a consistent view that perceived mobile payment security has a positive impact on users' attitude towards mobile payment usage (Shah, Peikari, \& Yasin, 2014). The higher the perceived safety of consumers, the fewer use risks they perceive and are, therefore, more willing to adopt the technology (Fan, Shao, Li, \& Xuemei, 2017). Security can be a significant challenge when building a Mobile Payment system to encourage consumers to use the platform (Widyastuti, Handayani, Pinem, \& Wilarso, 2017). Finally, in the context of e-commerce, Trust has received considerable attention due to the great uncertainty and risk involved in online transactions. Trust has been find to impact the adoption of different services by users, such as Internet banking $(\mathrm{H}$. P. Lu \& Su, 2009). Trust already should be one of the factors that affect online transactions because individuals do not have direct control with merchants (Roca, García, \& de la Vega, 2009). Trust has also become a fundamental predictor of Behavioral Intention (Suh \& Han, 2003; Zhou, 2013).

Based on the discussion above, the present study will evaluate the relationship between the latent variables to determine the factors that are significantly affecting behavioral intention to use mobile payment. The subsequent sections will discuss the methods being used in this study, followed by the results and analysis section, before finishing the study with the discussion section.

\section{RESEARCH METHODOLOGY}

In this study, the researchers use several tools to obtain as much data and information from various sources. Quantitative method is used in this research by spreading online questionnaires to collect the data to investigate the relationships between the latent variables. The measurement model consists of 35 statements (except for the filtering questions and demographic questions). A Likert scale between 1 and 5 is used in this research. According to Sekaran and Bougie (2016), Likert scale is a scale to measure the attitude of respondents in a validated way. The scope of this research is to analyze the path relationships between Performance Expectancy, Effort Expectancy, Social Influence, Hedonic Motivation, Facilitating Condition, Perceived Security, Trust, and Behavioral Intention. The study was limited to users of LinkAja who lived in the Greater Jakarta (Jabodetabek) area as the largest megapolitan in Indonesia. In total, the researchers managed to gather 175 responses, but after the data screening and application of Mahalanobis distance to detect outliers, the researchers ended up with 144 respondents for further analyses. 


\section{ANALYSIS AND DISCUSSION}

\section{Analysis}

The analysis in the current research uses the Structural Equation Model with Partial Least Square approach (SEM-PLS). According to Garson (2016), there are two sub-models used in PLS methods, namely, the outer model (also known as the measurement model) and the inner model (also known as the structural model).

Outer Model Analysis

To determine if there is any relationship between the related constructs, a convergent validity test is conducted. The test is based on the values of the outer loading and the Average Variance Extracted (AVE). Ideally, the outer loadings should be >0.7, while AVE $\geq 0.5$ (Hair, Black, Babin, \& Anderson, 2019). In this study, all outer loadings were found to be above 0.7, ranging between 0.734 and 0.931 . The results also found all the AVE values to be more than 0.5 , ranging between 0.662 and 0.816 . Therefore, it can be concluded that all the data have met the criteria for convergent validity and can be considered to be "valid". Additionally, to test the discriminant validity, the researchers have found that the all outer loadings are significantly predicting their respective constructs and there are no "cross-loadings" in which any of the observed variables measured other constructs with relatively high factor loading. Hence, it can be concluded that the discriminant validity in this study has been achieved. Furthermore, the reliability test is also performed in this study to ensure that the measurements used here can be replicated and are reliable. According to Hair et al. (2019), the reliability of the data is tested by looking at the Cronbach's Alpha (CA>0.7) and Composite Reliability $(\mathrm{CR}>0.7)$. As can be seen in Table 2, all constructs in this study have met the criteria for the reliability test.

Table 2. Outer Model Measurements

Source: Data processed in SmartPLS 3

\begin{tabular}{cccc}
\hline & $\begin{array}{c}\text { Cronbach's } \\
\text { Alpha }\end{array}$ & $\begin{array}{c}\text { Composite } \\
\text { Reliability }\end{array}$ & AVE \\
\hline Threshold & $>0.7$ & $>0.7$ & $\geq 0.5$ \\
\hline BI & 0.919 & 0.943 & 0.805 \\
\hline EE & 0.846 & 0.896 & 0.684 \\
\hline FC & 0.745 & 0.854 & 0.662 \\
\hline HM & 0.882 & 0.919 & 0.739 \\
\hline PE & 0.902 & 0.925 & 0.672 \\
\hline PS & 0.887 & 0.930 & 0.816 \\
\hline SI & 0.862 & 0.916 & 0.784 \\
\hline T & 0.915 & 0.933 & 0.664 \\
\hline
\end{tabular}

Inner Model Analysis

To test the hypotheses in this study, the researchers bootstrapped the data on SmartPLS and came up with the results of the path analysis and coefficient of determination. The results of the structural model analysis can be seen in Table 3 and Figure 1.

Table 3. Inner Model Measurements

Source: Data processed in SmartPLS 3

\begin{tabular}{ccccc}
\hline Path & Estimate & $\boldsymbol{t}$-value & p-value & Decision \\
\hline $\mathbf{E E} \rightarrow \mathbf{B I}$ & 0.059 & 0.750 & 0.454 & Not supported \\
\hline $\mathbf{E E} \rightarrow \mathbf{P E}$ & 0.392 & 5.298 & 0.000 & Supported \\
\hline $\mathbf{S I} \rightarrow \mathbf{B I}$ & 0.240 & 3.259 & 0.001 & Supported \\
\hline $\mathbf{S I} \rightarrow \mathbf{P E}$ & 0.440 & 7.189 & 0.000 & Supported \\
\hline
\end{tabular}




\begin{tabular}{ccccc}
\hline Path & Estimate & $\boldsymbol{t}$-value & p-value & Decision \\
\hline $\mathbf{F C} \rightarrow$ BI & 0.066 & 0.878 & 0.380 & Not supported \\
\hline $\mathbf{F C ~} \rightarrow$ PE & 0.103 & 1.287 & 0.199 & Not supported \\
\hline $\mathbf{H M ~} \rightarrow$ BI & 0.340 & 2.826 & 0.005 & Supported \\
\hline $\mathbf{P S} \rightarrow$ BI & 0.029 & 0.377 & 0.706 & Not supported \\
\hline $\mathbf{P S} \rightarrow \mathbf{T}$ & 0.535 & 8.482 & 0.000 & Supported \\
\hline $\mathbf{P E} \rightarrow \mathbf{B I}$ & 0.007 & 0.066 & 0.948 & Not supported \\
\hline $\mathbf{P E} \rightarrow \mathbf{T}$ & 0.472 & 7.306 & 0.000 & Supported \\
\hline $\mathbf{T} \rightarrow \mathbf{B I}$ & 0.276 & 2.669 & 0.008 & Supported \\
\hline
\end{tabular}

The results of the current study also revealed an adjusted $\mathrm{R}^{2}$ of 0.716 , which means that the endogenous variables in this study explain the variation in the endogenous variable (i.e., Behavioral Intention) by 71.6 percent (which is substantial), while the rest is explained by other variables which are not part of this study.

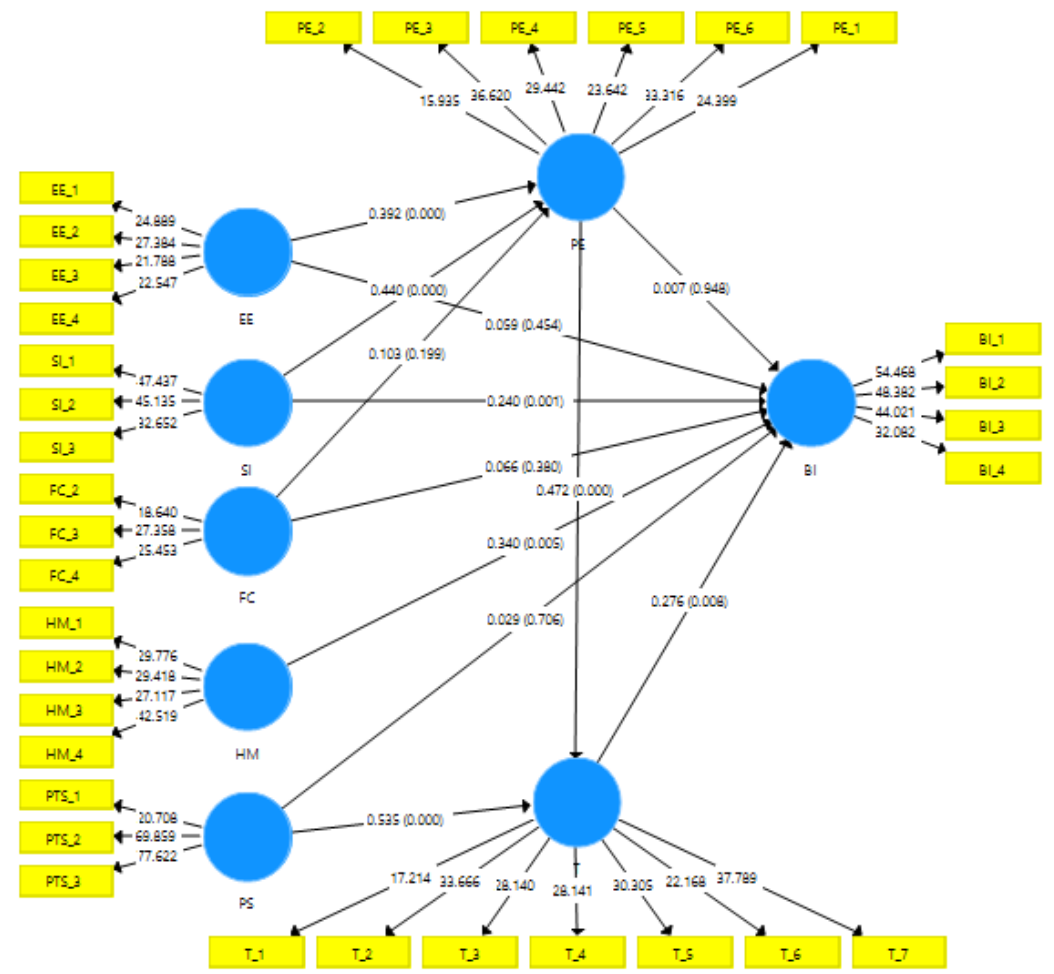

Figure 1. Structural Model

\section{Discussion}

Source: Data processed by SmartPLS 3.2.8

From Table 3, it can be observed that Effort Expectancy was not found to be significantly related to Behavioral Intention. This can be seen from the $t$-value of $0.750(t<1.96)$ and $p$-value of 0.454 (p>0.05). Various studies in the past supported this finding (e.g., Oliveira et al., 2016; Slade, Dwivedi, Piercy, \& Williams, 2015; Tarhini, El-Masri, Ali, \& Serrano, 2016). Conversely, Effort Expectancy was found to have a significant relationship with Performance Expectancy (t-value 5.298; p-value 0.000), with a regression weight of 0.392. This is in line with Boes, Borde, and Egger (2015). Social Influence in this study was found to significantly predict Behavioral Intention. This is observable from the $t$-value of $3.259(t>1.96)$ and $p$-value of $0.001(p<0.05)$. This finding is supported by the previous study by Martins, Oliveira, and Popovič (2014). Social Influence was also significantly predicting Performance Expectancy with a t-value of 7.189 $(\mathrm{t}>1.96)$ and a $\mathrm{p}$-value of $0.000(\mathrm{p}<0.05)$. The result indicates the importance of social influence 
in shaping user's assessment vis-à-vis the usefulness of LinkAja as a mobile payment platform. This finding is also in keeping with the results of Teo, Zhou, Fan, and Huang (2019).

When it comes to Facilitating Condition, the results of this study show that it did not have any significant relationships with both Behavioral Intention (t-value 0.878; p-value 0.380) and Performance Expectancy (t-value 1.287; p-value 0.199). The results imply that users of LinkAja do not consider the supporting elements to access the platform (e.g., the smartphone, internet access, supporting merchants) to be particularly helpful in predicting the intention to use as well as the usefulness and benefits of the system. In contrast, Hedonic Motivation was found to be significant in predicting Behavioral Intention (t-value 2.826; p-value 0.005). In other words, LinkAja could take advantage of this finding by focusing on the entertainment values that users can get by using LinkAja. This finding is similar to the results of Megadewandanu, Suyoto, and Pranowo (2017). Next, Perceived Security was not found to have a significant influence on Behavioral Intention, which is supported by Matos and Krielow (2019). This can be observed from the $\mathrm{t}$-value of $0.377(\mathrm{t}<1.96)$ and $\mathrm{p}$-value of $0.706(\mathrm{p}>0.05)$. However, Perceived Security was found to be a significant antecedent to Trust (t-value 8.482; p-value 0.000). Moreover, the effect between the two constructs was also found to be the highest compared to all the other paths in this study, at 0.535. This finding is supported by Chellappa and Pavlou (2002).

Performance Expectancy was not found to be a significant predictor of Behavioral Intention with a t-value of $0.066(\mathrm{t}<1.96)$ and $\mathrm{p}$-value of $0.948(\mathrm{p}>0.05)$. This is in line with the finding of Sobti (2019). On the other hand, Performance Expectancy was found to have a significant relationship to Trust (t-value 7.306; p-value 0.000), which means that the respondents of the present study would develop their trust in the mobile payment system if they consider the platform to be useful, reliable, and beneficial to them. This finding is similar to the results of Ramos, Ferreira, De Freitas, and Rodrigues (2018). Finally, Trust has a significant relationship with the Behavioral Intention based on the t-value of 2.669 and p-value of 0.008 . This is supported by earlier study by Lean et al. (2009).

\section{SUMMARY AND RECOMMENDATION Summary}

Based on the results of this study, seven hypotheses were supported by the data, while the other five were not supported. First, Effort Expectancy was not found to be significant in predicting Behavioral Intention to use mobile payment. However, since it was found to be significant with Performance Expectancy, it could indirectly affect the endogenous variable by going through the path route from Effort Expectancy $\rightarrow$ Performance Expectancy $\rightarrow$ Trust $\rightarrow$ Behavioral Intention which was all found to be significant. Second, Social Influence was found to be a significant antecedent to both Behavioral Intention and Performance Expectancy. This implies that LinkAja and other mobile payment platforms could attempt to persuade relevant reference groups with many followings to influence their target market to adopt the system. Third, Facilitating Condition was not found to be significant in influencing both Behavioral Intention and Performance Expectancy. In other words, users of LinkAja in the present study did not pay much attention to the supporting infrastructure of the system. Fourth, Hedonic Motivation was found to be a significant predictor of Behavioral Intention, which meant that LinkAja users in this research appreciated the entertainment value that mobile payment services had to offer. Fifth, Perceived Security was not found to significantly predicting Behavioral Intention. However, it was found to be a significant antecedent to Trust. While Perceived Security alone does not have a direct relationship with Behavioral Intention, but it indirectly affects the endogenous construct through Trust as the mediating variable. In other words, LinkAja needs to reinforce the system's 
security in order to increase its user's trust, and subsequently, behavioral intention to use. Sixth, similar to Perceived Security, Performance Expectancy did not have a direct relationship to Behavioral Intention. However, it could affect the latter through Trust as the mediating variable. Seventh, as has been established earlier, Trust was found to be a significant predictor of Behavioral Intention to Use and an essential mediating variable between Perceived Security/Performance Expectancy and Behavioral Intention.

\section{Recommendation}

For future studies, some suggestions can be taken into account. First, the data for the present study was only collected at a particular time. Future research on the topic can expand the study by capturing data longitudinally to gain a better insight on the phenomenon. The respondents of the current study were also limited to users of a single mobile payment provider, so future studies could expand this study by investigating other companies or the industry. Future researchers can also incorporate other variables not investigated in this study, such as Price and Habit (Venkatesh et al., 2012).

\section{Acknowledgement}

The researchers would like to acknowledge and express gratitude to the Ministry of Research and Technology/National Agency for Research and Innovation (RISTEK-BRIN) for supporting this study through the National Competitive Research Grant scheme.

\section{REFERENCES}

Alalwan, A. A., Dwivedi, Y. K., \& Rana, N. P. (2017). Factors influencing adoption of mobile banking by Jordanian bank customers: Extending UTAUT2 with trust. International Journal of Information Management, 37(3), 99-110. https://doi.org/10.1016/j.ijinfomgt.2017.01.002

Aydin, G., \& Burnaz, S. (2016). Adoption of mobile payment systems: A study on mobile wallets. Journal of Business, Economics and Finance, 5(1), 73-92. https://doi.org/10.17261/pressacademia.2016116555

Basari, M. T. (2019). Setahun, Jumlah Pengguna Internet Indonesia Bertambah 17 Juta Teknologi Bisnis.com. Retrieved March 30, 2020, from https://teknologi.bisnis.com/read/20190228/101/894799/setahun-jumlah-penggunainternet-indonesia-bertambah-17-juta

Boes, K., Borde, L., \& Egger, R. (2015). The Acceptance of NFC Smart Posters in Tourism. In eTourism: Transforming Mobility.

Chellappa, R. K., \& Pavlou, P. A. (2002). Perceived information security, financial liability and consumer trust in electronic commerce transactions. Logistics Information Management, 15(5/6), 358-368. https://doi.org/10.1108/09576050210447046

Davies, N., Taft, N., Satyanarayanan, M., Clinch, S., \& Amos, B. (2016). Privacy Mediators: Helping IoT cross the chasm (pp. 39-44). Association for Computing Machinery (ACM). https://doi.org/10.1145/2873587.2873600

Davis, F. D. (1989). Perceived Usefulness, Perceived Ease of Use, and User Acceptance of Information Technology. MIS Quarterly, 13(3), 319-340. https://doi.org/10.2307/249008

Elgin, C. (2013). Internet usage and the shadow economy: Evidence from panel data. Economic Systems, 37(1), 111-121. https://doi.org/10.1016/j.ecosys.2012.08.005

Fan, J., Shao, M., Li, Y., \& Xuemei, H. (2017). Understanding users' attitude toward mobile payment use: a comparative study. Industrial Management \& Data Systems, 118(3), 524540. https://doi.org/10.1108/IMDS-06-2017-0268

Garson, G. D. (2016). Partial Least Squares: Regression \& Structural Equation Models. 
Asheboro, NC: Statistical Associates Publishing.

Hair, J. F., Black, W. C., Babin, B. J., \& Anderson, R. E. (2019). Multivariate Data Analysis. Andover, Hampshire: Cengage Learning.

Hwang, R. J., Shiau, S. H., \& Jan, D. F. (2007). A new mobile payment scheme for roaming services. Electronic Commerce Research and Applications, 6(2), 184-191. https://doi.org/10.1016/j.elerap.2006.07.002

Jati, N. J., \& Laksito, H. (2012). Analisis Faktor-Faktor yang Mempengaruhi Minat Pemanfaatan dan Penggunaan Sistem E-Ticket (Studi Empiris pada Biro Perjalanan di Kota Semarang). Diponegoro Journal of Accounting, 1(1), 1-15.

Junadi, \& Sfenrianto. (2015). A Model of Factors Influencing Consumer's Intention to Use Epayment System in Indonesia. In Procedia Computer Science (Vol. 59, pp. 214-220). Elsevier. https://doi.org/10.1016/j.procs.2015.07.557

Kaczmarek, L. D., \& Mickiewicz, A. (2017). Hedonic Motivation. In V. Zeigler-Hill \& T. K. Shackelford (Eds.), Encyclopedia of Personality and Individual Differences. Basel: Springer.

Katadata.co.id. (2018). Wajib Registrasi, Pelanggan Seluler Indosat Menyusut 34\% | Databoks. Retrieved March 30, 2020, from https://databoks.katadata.co.id/datapublish/2018/11/19/wajib-registrasi-pelangganseluler-indosat-menyusut-34

Katadata.co.id. (2019). LinkAja, Koalisi 7 BUMN Saingi Go-Pay dan OVO - Infografik Katadata.co.id. Retrieved March 31, 2020, from https://katadata.co.id/infografik/2019/03/11/linkaja-koalisi-7-bumn-saingi-go-pay-danovo

Kim, C., Mirusmonov, M., \& Lee, I. (2010). An empirical examination of factors influencing the intention to use mobile payment. Computers in Human Behavior, 26(3), 310-322. https://doi.org/10.1016/j.chb.2009.10.013

Lancelot Miltgen, C., Popovič, A., \& Oliveira, T. (2013). Determinants of end-user acceptance of biometrics: Integrating the "big 3" of technology acceptance with privacy context. Decision Support Systems, 56(1), 103-114. https://doi.org/10.1016/j.dss.2013.05.010

Lean, O. K., Zailani, S., Ramayah, T., \& Fernando, Y. (2009). Factors influencing intention to use e-government services among citizens in Malaysia. International Journal of Information Management, 29(6), 458-475. https://doi.org/10.1016/j.ijinfomgt.2009.03.012

Lu, H. P., \& Su, P. Y. J. (2009). Factors affecting purchase intention on mobile shopping web sites. Internet Research, 19(4), 442-458. https://doi.org/10.1108/10662240910981399

Lu, Y., Yang, S., Chau, P. Y. K., \& Cao, Y. (2011). Dynamics between the trust transfer process and intention to use mobile payment services: A cross-environment perspective. Information and Management, 48(8), 393-403. https://doi.org/10.1016/j.im.2011.09.006

Martins, C., Oliveira, T., \& Popovič, A. (2014). Understanding the internet banking adoption: A unified theory of acceptance and use of technology and perceived risk application. International Journal of Information Management, 34(1), 1-13. https://doi.org/10.1016/j.ijinfomgt.2013.06.002

Matos, C. A. de, \& Krielow, A. (2019). The effects of environmental factors on B2B e-services purchase: perceived risk and convenience as mediators. Journal of Business and Industrial Marketing, 34(4), 767-778. https://doi.org/10.1108/JBIM-12-2017-0305

Megadewandanu, S., Suyoto, \& Pranowo. (2017). Exploring mobile wallet adoption in Indonesia using UTAUT2: An approach from consumer perspective. Proceedings - 2016 2nd International Conference on Science and Technology-Computer, ICST 2016, 11-16. https://doi.org/10.1109/ICSTC.2016.7877340 
Multazam, M. (2019). Terlena Dompet Digital. Retrieved March 30, 2020, from https://news.detik.com/kolom/d-4463578/terlena-dompet-digital

Oliveira, T., Thomas, M., Baptista, G., \& Campos, F. (2016). Mobile payment: Understanding the determinants of customer adoption and intention to recommend the technology. Computers in Human Behavior, 61(2016), 404-414. https://doi.org/10.1016/j.chb.2016.03.030

Pertiwi, W. K. (2019). T-Cash Berubah Jadi LinkAja Mulai Hari Ini. Retrieved March 31, 2020, from https://tekno.kompas.com/read/2019/02/22/09120087/t-cash-berubah-jadi-linkajamulai-hari-ini

Phonthanukitithaworn, C., Sellitto, C., \& Fong, M. W. L. (2016). An investigation of mobile payment (m-payment) services in Thailand. Asia-Pacific Journal of Business Administration, 8(1), 37-54. https://doi.org/10.1108/APJBA-10-2014-0119

Popovska-Kamnar, N. (2014). The use of electronic money and its impact on monetary policy. Journal of Contemporary Economic and Business Issues, 1(2), 79-92. Retrieved from http://hdl.handle.net/10419/147460

Ramos, F. L., Ferreira, J. B., De Freitas, A. S., \& Rodrigues, J. W. (2018). The effect of trust in the intention to use m-banking. Brazilian Business Review, 15(2), 175-191. https://doi.org/10.15728/bbr.2018.15.2.5

Roca, J. C., García, J. J., \& de la Vega, J. J. (2009). The importance of perceived trust, security and privacy in online trading systems. Information Management and Computer Security, 17(2), 96-113. https://doi.org/10.1108/09685220910963983

Saha, G. C., \& Theingi. (2009). Service quality, satisfaction, and behavioural intentions: A study of low-cost airline carriers in Thailand. Managing Service Quality, 19(3), 350-372. https://doi.org/10.1108/09604520910955348

Schierz, P. G., Schilke, O., \& Wirtz, B. W. (2010). Understanding consumer acceptance of mobile payment services: An empirical analysis. Electronic Commerce Research and Applications, 9(3), 209-216. https://doi.org/10.1016/j.elerap.2009.07.005

Sekaran, U., \& Bougie, R. (2016). Research methods for business: A skill building approach. John Wiley \& Sons, Ltd.

Shah, M. H., Peikari, H. R., \& Yasin, N. M. (2014). The determinants of individuals' perceived e-security: Evidence from Malaysia. International Journal of Information Management, 34(1), 48-57. https://doi.org/10.1016/j.ijinfomgt.2013.10.001

Sheikh, Z., Islam, T., Rana, S., Hameed, Z., \& Saeed, U. (2017). Acceptance of social commerce framework in Saudi Arabia. Telematics and Informatics, 34(8), 1693-1708. https://doi.org/10.1016/j.tele.2017.08.003

Shiau, H. C. (2014). The impact of product innovation on behavior intention: The measurement of the mediating effect of the brand image of Japanese anime dolls. Anthropologist, 17(3), 777-788. https://doi.org/10.1080/09720073.2014.11891492

Slade, E. L., Dwivedi, Y. K., Piercy, N. C., \& Williams, M. D. (2015). Modeling Consumers' Adoption Intentions of Remote Mobile Payments in the United Kingdom: Extending UTAUT with Innovativeness, Risk, and Trust. Psychology \& Marketing, 32(8), 860-873. https://doi.org/10.1002/mar.20823

Sobti, N. (2019). Impact of demonetization on diffusion of mobile payment service in India: Antecedents of behavioral intention and adoption using extended UTAUT model. Journal of Advances in Management Research, 16(4), 472-497. https://doi.org/10.1108/JAMR-09-2018-0086

Suh, B., \& Han, I. (2003). The Impact of Customer Trust and Perception of Security Control on the Acceptance of Electronic Commerce. International Journal of Electronic Commerce, 7(3), 
http://mesharpe.metapress.com/index/925wunk9efe9n95a.pdf\%5Cnpapers3://publication/ uuid/44CFEC88-C9E5-443D-AE9C-7D1E8898921E

Tarhini, A., El-Masri, M., Ali, M., \& Serrano, A. (2016). Extending the UTAUT model to understand the customers' acceptance and use of internet banking in Lebanon. Information Technology \& People, 29(4), 830-849. https://doi.org/10.1108/itp-02-20140034

Teo, T., Zhou, M., Fan, A. C. W., \& Huang, F. (2019). Factors that influence university students' intention to use Moodle: a study in Macau. Educational Technology Research and Development, 67(3), 749-766. https://doi.org/10.1007/s11423-019-09650-x

Van Der Heijden, H. (2004). User Acceptance of Hedonic Information Systems. MIS Quarterly, 28(4), 695-704. https://doi.org/10.2307/25148660

Venkatesh, V., Morris, M. G., Davis, G. B., \& Davis, F. D. (2003). User Acceptance of Information Technology: Toward a Unified View. MIS Quarterly, 27(3), 425-478.

Venkatesh, V., Thong, J. Y. L., \& Xu, X. (2012). Consumer Acceptance and Use of Information Technology: Extending the Unified Theory of Acceptance and Use of Technology. MIS Quarterly, 36(1), 157. https://doi.org/10.2307/41410412

Widyastuti, K., Handayani, P. W., Pinem, A. A., \& Wilarso, I. (2017). e-Money Implementation Barriers and Challenges: A Case of Indonesia Interbank Network Company. Journal of Engineering and Applied Sciences, 12(12), 3281-3285. https://doi.org/10.36478/jeasci.2017.3281.3285

Wijoseno, J., \& Ariyanti, M. (2017). Perceived Factors Influencing Consumer Trust and Its Impact on Online Purchase Intention in Indonesia. International Journal of Science and Research, 6(8), 961-968. https://doi.org/10.21275/8081706

Zhou, T. (2013). An empirical examination of continuance intention of mobile payment services. Decision Support Systems, 54(2), 1085-1091. https://doi.org/10.1016/j.dss.2012.10.034

Zhou, T., Lu, Y., \& Wang, B. (2010). Integrating TTF and UTAUT to explain mobile banking user adoption. Computers in Human Behavior, 26(4), 760-767. https://doi.org/10.1016/j.chb.2010.01.013 